\title{
RELATIONSHIP BETWEEN SPORTS EXPERIENCE AND ANTHROPOMETRIC INDICES AND SPORT PERFORMANCE IN WORLD WOMEN'S HANDBALL CHAMPIONSHIP'2009
}

\author{
Audinga Kniubaitė, Antanas Skarbalius \\ Lithuanian Academy of Physical Education, Kaunas, Lietuva
}

\begin{abstract}
Research background and hypothesis. The increasing demand for ever higher top level has meant greater interest and research into the factors which influence performance and sporting achievements. Handball is a complex sport whereby performance can be analyzed and presented in a variety of ways. We hypothesized that teams with players with higher anthropometric indices and greater sporting experience had better possibilities in winning a match-play.

Research aim was to assess the interaction between players' height, body mass, body mass index (BMI), age, sports experience and sport performance in the World Women's Handball Championship'2009 (WWHC'2009).

Research methods. The data sets were collected from the IHF website (http//www.ihf.info). We analyzed the height, body mass, body mass index (BMI), sporting experience (international matches played and goals scored) of 390 players as well as their influence on winning points (Pearson's correlation) and final ranking position (Spearman's Correlation) of WWHC'2009.

Research results. Champions from Russia, the first four seat players and European women players were greater in body size (height, body mass), and sports experience.

Discussion and conclusions. Teams composed of players with greater experience had more possibilities to win $\left(\mathrm{r}=0.719 ; \mathrm{p}<0.001 ; \mathrm{Y}=0.1571 \mathrm{x}+4.9104 ; \mathrm{r}^{2}=0.5183\right)$, but body mass had negative influence $(\mathrm{r}=0.317$; $\left.\mathrm{Y}=0.5353 \mathrm{x}-25.598 ; \mathrm{r}^{2}=0.1008\right)$ as well as BMI $\left(\mathrm{r}=-0.3300 ; \mathrm{Y}=-2.0762 \mathrm{x}+57.273 ; \mathrm{r}^{2}=0.1089\right)$. The height of players had moderate influence $(r=0.551 ; \mathrm{p}<0.001)$ on wining a match-play. It should be noted that the players in the last elite-level competition (European Women's Handball Championship'2010) showed the same tendency and were taller and heavier than the players of WWHC'2009.
\end{abstract}

Keywords: Women's Handball, body mass, height.

\section{INTRODUCTION}

A thletes with specific body structure characteristic of a particular sport have gained significant achievements in sports (Norton, Olds, 2001). However, considering the development of sports and the permanent changes of athletes in the national teams, it is necessary to study the changes in athletes' body composition permanently (Jones et al., 2008).

It has been asserted that handball players' physique (body mass, height) as well as of those in other sports, has a significant impact on athletic outcomes (Bayios et al., 2006; Massuca, 2011; Michalsik et al., 2011). However, the results are sometimes quite controversial, unique to the sample of high skilled or elite athletes. The influence of anthropometric indicators (height, body mass) on sports performance in elite sport might be at different levels: moderate or even insignificant (Bezerra, Simão, 2006). For this reason, it is necessary to establish the trends of interaction between body composition and sport performance permanently. 
To date, most of the literature on team handball focuses on elite men's handball players' anthropometric characteristics, competition experience and their interaction with athletic performance. Only a few studies have evaluated peculiarities and tendencies of sport performance in elite women's handball. However, there is no publication related to the last Women's World Handball Championship'2009 (WWHC'2009). It is highly important to find out the influence of body composition (height and body mass, body mass index [BMI]), age, sports experience (international matches played and the goals scored) indicators on sport performance; thus, to carry out discriminant analyses between winners and losers in elite women modern handball.

The hypothesis. The team whose players were higher, had greater body mass and sports experience had better possibilities in winning the match and rank in WWHC'2009.

The aim of the study was to assess the peculiarities of sport performance in WWHC'2009 and the influence of player's body composition, age, sports experience on sport performance.

\section{RESEARCH METHODS}

The data sets were collected from the International Handball Federation (IHF) website (http//ww.ihf.info) cover database of the WWHC'2009. We used the data about 24 teams with 390 players, their anthropometric characteristics (height, body mass and body mass index), age, sports experience (international matches played and the goals scored). Body mass index (BMI) was calculated by the formula (Carter, 1984) BMI $=$ body mass $(\mathrm{kg}) /$ height $^{2}(\mathrm{~m})$. The indicators of champions, teams winning of 1-4, 5-12 and 13-24 places, and between teams representing continents were compared. The level of significance was conducted at $\mathrm{p}<0.05$, and the magnitude between values was assessed by using standard effect size (ES) analysis procedures (Hopkins, 2006) using previously established scales (Hopkins, 2002): trivial $<0.2$, small $0.2-0.6$, moderate $0.6-1.2$, large $1.2-2.0$, very large $>2.0$. Pearson's product moment correlation was used to examine the relationships between the analysed indicators and winning points, and Spearman's correlation coefficient was used to evaluate relationships in ranking places. The indicators of champions, teams winning 1-4, 5-12 and 13-24 places, and between have representing different continents were compared using a general linear model analysis of variance (ANOVA), with Tukey Post Hoc test using Excel 2003 and statistical package SPSS 17.0.

\section{RESEARCH RESULTS}

Height. The height was typical of teams which took higher places in the ranking scale (Table 1, $2)$. The champions - Russian players $(p<0.01$; $\mathrm{ES}=0.850$ [moderate]), the players of 1-4 teams $(\mathrm{p}<0.01 ; \mathrm{ES}=0.450$ [small]), and European handball players $(\mathrm{p}<0.001 ; \mathrm{ES}=0.349$ [small] $)$ were higher than the tournament player on average (Table 1). Players of 13-24 teams $(\mathrm{p}<0.01$; $\mathrm{ES}=0.252$ [small]), players of Africa $(\mathrm{p}<0.02$; $\mathrm{ES}=0.320$ [small] $)$, and America $(\mathrm{p}<0.01$; $\mathrm{ES}=0.437$ [small]) continents were smaller than the tournament player on average. Russian players exceeded the players of the lowest 5-12 teams $(\mathrm{p}<0.01 ; \mathrm{ES}=0.746$ [moderate]), and of 13-24 teams $(\mathrm{p}<0.001$; $\mathrm{ES}=1.085$ [moderate] $)$ in the ranking scale. African ( $\mathrm{p}<0.001 ; \mathrm{ES}=1.218$ [large]), American ( $<<0.001 ; \mathrm{ES}=1.27$ [moderate]), Asian $(\mathrm{p}<0.001 ; \mathrm{ES}=1.015$ [moderate] $)$, Australian $(\mathrm{p}<0.01 ; \mathrm{ES}=0.957$ [moderate] $)$ and European handball players $(\mathrm{p}<0.05 ; \mathrm{ES}=0.545$ [small] $)$ were smaller than Russian players. Players of 1-4 teams were taller than players of 5-12 $(\mathrm{p}<0.05 ; \mathrm{ES}=0.309$ [small] $)$ and of 13-24 $(\mathrm{p}<0.001 ; \mathrm{ES}=0.703$ [moderate] $)$ teams, as the players of $5-12$ teams $(\mathrm{p}<0.001 ; \mathrm{ES}=0.436)$ compared to the lowest (13-24) ones. European handball players were significantly taller $(\mathrm{p}<0.001)$ compared to handball players of the continents of Africa $(\mathrm{ES}=0.707$ [moderate]), America $(\mathrm{ES}=0.804$ [moderate]) and Asia (ES $=0.540$ [small]), but not significantly higher $(\mathrm{p}>0.05 ; \mathrm{ES}=0.416$ [small] $)$ than the players of Australian continent.

Body mass. Variation of body mass was opposite to the height (Table 1, 2). Teams including players with the heavier body mass took lower places. Asian handball players had statistically significantly $(\mathrm{p}<0.01 ; \mathrm{ES}=0.365$ [small]) lower body mass than the tournament player on average. Russian players were heavier in their body mass than the players of $5-12$ teams $(\mathrm{p}<0.02 ; \mathrm{ES}=0.613$ [moderate), Asian ( $\mathrm{p}<0.01 ; \mathrm{ES}=0.883$ [moderate] $)$ and American handball players $(\mathrm{p}<0.05 ; \mathrm{ES}=0.333$ [small]). The players of $1-4$ teams were heavier in their body mass $(\mathrm{p}<0.05 ; \mathrm{ES}=0.373$ [small] $)$ than players of 5-12 teams. European handball players were heavier $(\mathrm{p}<0.001$; ES $=0.548$ [small] $)$ compared to players of the Asian continent, but 
not significantly ( $p>0.05)$ compared to players of other continents. Asian handball players had less body mass $(\mathrm{p}<0.01 ; \mathrm{ES}=0.503$ [small]) compared to players of the African continent.

Body mass index. BMI indicator was adequate to body mass (Tables 1, 2). BMI of Asian players $(\mathrm{p}<0.01 ; \mathrm{ES}=0.349$ [small] $)$ and players of lower 5-12 teams were smaller $(\mathrm{p}<0.01$; ES $=$ 0.286 [small]) than that of the tournament player on average. BMI of African players were higher $(\mathrm{p}<0.001 ; \mathrm{ES}=0.489$ [small] $)$ than that of the tournament player on average. Players of 5-12 teams had lower $(\mathrm{p}<0.001$; ES $=0.482$ [small] $)$ BMI than players of 13-24 teams. African handball players had greater BMI than Russian handball players $(\mathrm{p}<0.05 ; \mathrm{ES}=0.773$ [moderate]). BMI of African players $(\mathrm{p}<0.01 ; \mathrm{ES}=0.642$ [moderate] $)$ and American $(\mathrm{p}<0.02 ; \mathrm{ES}=0.056$ [trivial] $)$ players were less compared to the ones of players of the European continent. BMI of Asian handball players were significantly less $(\mathrm{p}<0.001)$ compared to the ones of players of Africa ( $\mathrm{ES}=0.815$ [moderate]) and America ( $\mathrm{ES}=0.090$ [trivial]).

Age. African handball players were older $(\mathrm{p}<$ 0.01 ; $\mathrm{ES}=0.350$ [small]), Asian handball players were younger $(\mathrm{p}<0.02 ; \mathrm{ES}=0.318$ [small]) than the tournament player on average. The players of 1-4 teams were older than players of 5-12 teams $(\mathrm{p}<0.05 ; \mathrm{ES}=0.301$ [small]). European handball players were significantly older than the Asians ( $p<0.001$; $\mathrm{ES}=0.495$ [small]), Americans $(\mathrm{p}<0.05 ; \mathrm{ES}=0.380$ [small]) and Australians ( $\mathrm{p}<$ $0.05 ; \mathrm{ES}=0.504$ [small]), but not significantly older $(\mathrm{p}>0.05)$ than the Africans. African handball players were older than Asian $(\mathrm{p}<0.001$; ES $=$ 0.659 [moderate]), Australian ( $\mathrm{p}<0.02 ; \mathrm{ES}=0.649$ [moderate]) and American ( $<<0.01 ; \mathrm{ES}=0.567$ [small]) handball players, but insignificantly older than European players ( $p>0.05)$.

Sports experience (international matches played). The players of $1-4$ teams $(p<0.02$; $\mathrm{ES}=0.312$ [small] $)$ and European $(\mathrm{p}<0.05$; ES $=$ 0.205 [small]) handball players had played more international matches than the tournament player on average (Tables 1, 2). Players of lowest 13-24 teams ( $\mathrm{p}<0.01 ; \mathrm{ES}=0.284$ [small]) and Australian $(\mathrm{p}<0.01 ; \mathrm{ES}=1.051$ [moderate]) handball players had played fewer international matches than the tournament player on average. Russian players had played more international matches than Australian players ( $\mathrm{p}<0.01$; ES $=1.307$ [large]). Players of the lowest 13-24 teams had played significantly fewer

Table 1. Body size, sports experience of players of different continents and ranking scale at WWHC'2009 ( $\bar{x} \pm s)$

\begin{tabular}{|c|c|c|c|c|c|c|}
\hline Players & $\begin{array}{l}\text { Height, } \\
\text { cm }\end{array}$ & $\begin{array}{c}\text { Body mass, } \\
\text { kg }\end{array}$ & BMI & $\begin{array}{l}\text { Age, } \\
\text { years }\end{array}$ & $\begin{array}{c}\text { International } \\
\text { matches played }\end{array}$ & $\begin{array}{l}\text { Goals } \\
\text { scored }\end{array}$ \\
\hline Mean, $n=390$ & $174.6 \pm 7.1$ & $68.4 \pm 7.9$ & $22.1 \pm 1.1$ & $24 \pm 3.7$ & $46 \pm 47$ & $111 \pm 146$ \\
\hline $\begin{array}{l}\text { Champions, } \\
\mathrm{n}=16\end{array}$ & $\begin{array}{c}180.5 \pm 6.7 \\
* * *\end{array}$ & $72.3 \pm 7.5$ & $22.4 \pm 1.9$ & $24 \pm 3.7$ & $53 \pm 44$ & $136 \pm 155$ \\
\hline $\begin{array}{l}1-4^{\text {th }} \text { places, } \\
n=67\end{array}$ & $\begin{array}{c}177 \pm 6.3 \\
* * *\end{array}$ & $70.6 \pm 7.5$ & $22.3 \pm 1.8$ & $25 \pm 3.8$ & $\begin{array}{l}62 \pm 54 \\
* *\end{array}$ & $149 \pm 149$ \\
\hline $\begin{array}{l}5-12^{\text {th }} \text { places, } \\
n=133\end{array}$ & $\begin{array}{c}175.7 \pm 6 \\
\& \& \&\end{array}$ & $67.8 \pm 7$ & $\begin{array}{c}21.9 \pm 1.6 \\
* * *\end{array}$ & $24 \pm 3.8$ & $51 \pm 48$ & $121 \pm 153$ \\
\hline $\begin{array}{l}13-24^{\text {th }} \text { places } \\
n=190\end{array}$ & $\begin{array}{l}172.7 \pm 7.5 \\
* * * \& \& \& \&\end{array}$ & $\begin{array}{c}68.2 \pm 8.4 \\
\& \&\end{array}$ & $22.8 \pm 2$ & $24 \pm 4.2$ & $\begin{array}{l}34 \pm 40 \\
* * *\end{array}$ & $84 \pm 128$ \\
\hline $\begin{array}{l}\text { European continent } \\
\text { players, } n=179\end{array}$ & $\begin{array}{c}177 \pm 6.3 \\
* * * * \&\end{array}$ & $69.6 \pm 6.9$ & $22.2 \pm 1.5$ & $25 \pm 3.7$ & $\begin{array}{c}56 \pm 50 \\
*\end{array}$ & $133 \pm 148$ \\
\hline $\begin{array}{l}\text { Asian } \\
\text { continent players, } \\
\mathrm{n}=83\end{array}$ & $\begin{array}{c}173.2 \pm 7.7 \\
\& \& \& \& \\
\text { a@@@ }\end{array}$ & $\begin{array}{l}65.5 \pm 7.9 \\
* * * \& \& \& \\
\text {a@@@ }\end{array}$ & $\begin{array}{c}21.8 \pm 1.7 \\
* * *\end{array}$ & 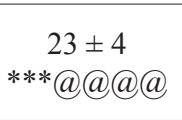 & $\begin{array}{l}35 \pm 43 \\
\text { @@@ }\end{array}$ & $\begin{array}{c}81 \pm 128 \\
\text { @ }\end{array}$ \\
\hline $\begin{array}{l}\text { American continent } \\
\text { players, } n=48\end{array}$ & $\begin{array}{c}171.4 \pm 7.5 \\
* * * \& \& \& \& \\
\text { @@@@ }\end{array}$ & $\begin{array}{c}69.8 \pm 7.4 \\
\&\end{array}$ & $\begin{array}{c}23.4 \pm 2.3 \\
\text { a@ }\end{array}$ & $\begin{array}{c}23 \pm 3.2 \\
\text { @ }\end{array}$ & $47 \pm 33$ & $193 \pm 67$ \\
\hline $\begin{array}{l}\text { African } \\
\text { continent players, } \\
\mathrm{n}=66\end{array}$ & $\begin{array}{c}172.4 \pm 6.5 \\
* * \& \& \& \& \\
\text { @@@@ }\end{array}$ & $69.8 \pm 9.2$ & $\begin{array}{c}22.9 \pm 1.7 \\
* * * * \\
\text { \&\&\&\&@@@ }\end{array}$ & $\begin{array}{l}25 \pm 4.2 \\
* *\end{array}$ & $\begin{array}{l}34 \pm 49 \\
@ @ @\end{array}$ & $101 \pm 193$ \\
\hline $\begin{array}{l}\text { Australian } \\
\text { continent players, } \\
\mathrm{n}=14\end{array}$ & $\begin{array}{l}174.4 \pm 6 \\
\& \& \&\end{array}$ & $68.7 \pm 8.8$ & $22.5 \pm 2.2$ & $\begin{array}{c}22 \pm 5 \\
\text { @ }\end{array}$ & $\begin{array}{c}10 \pm 20 \\
* * * \& \& \& \\
\text { a@@@ }\end{array}$ & $\begin{array}{c}16 \pm 26 \\
* \& \& \\
\text { a@@@ }\end{array}$ \\
\hline
\end{tabular}

Note. ${ }^{*}-\mathrm{p}<0.05 ; * *-\mathrm{p}<0.02 ; * * *-\mathrm{p}<0.01 ; * * * *-\mathrm{p}<0.001$ compared with the average value; \& $-\mathrm{p}<0.05 ; \& \& \&-\mathrm{p}<0.01 ; \& \& \& \&-$ $\mathrm{p}<0.001$ compared with champion's value; @-p $<0.05 ; @ @-\mathrm{p}<0.02 ;$ @@@-p $<0.01$; @@@@-p $<0.001$ compared with European value. 
Table 2. Body size, sports experience of players of different teams at WWHC'2009 ( $\bar{x} \pm s)$

\begin{tabular}{|c|c|c|c|c|c|c|}
\hline \multirow[b]{2}{*}{ Country } & \multirow{2}{*}{$\begin{array}{c}\text { Height, } \\
\text { cm }\end{array}$} & \multirow{2}{*}{$\begin{array}{c}\text { Body mass, } \\
\text { kg }\end{array}$} & \multirow[b]{2}{*}{ BMI } & \multirow{2}{*}{$\begin{array}{l}\text { Age, } \\
\text { years }\end{array}$} & \multicolumn{2}{|c|}{ Sports experience } \\
\hline & & & & & $\begin{array}{c}\text { International } \\
\text { matches } \\
\text { played }\end{array}$ & Goals scored \\
\hline Russia & $180.5 \pm 6.7 * * *$ & $72.3 \pm 7.5$ & $22.1 \pm 1.1$ & $24 \pm 3.7$ & $53 \pm 44$ & $136 \pm 155$ \\
\hline France & $177 \pm 5.9$ & $69.2 \pm 7.5$ & $21.9 \pm 1.9$ & $24 \pm 3.8$ & $51 \pm 44 * * * *$ & $110 \pm 93 * *$ \\
\hline Norway & $178.1 \pm 4.9^{*}$ & & & $26.6 \pm 3^{*}$ & $87 \pm 70$ & $204 \pm 198$ \\
\hline Spain & $175.1 \pm 7.1$ & $70.4 \pm 7.6$ & $22.9 \pm 2.2$ & $26 \pm 4.6$ & $57 \pm 49$ & $144 \pm 175$ \\
\hline Denmark & $175.5 \pm 6.1$ & $70.6 \pm 7.1$ & $22.8 \pm 1.3$ & $25 \pm 3.9$ & $54 \pm 40$ & $98 \pm 46$ \\
\hline Korea & $172.4 \pm 5.4$ & $62.3 \pm 6.4^{* * *}$ & $20.9 \pm 1.4 * * *$ & $24 \pm 4.4$ & $67 \pm 51 * *$ & $182 \pm 179$ \\
\hline Germany & $176.2 \pm 7.5$ & $69.6 \pm 6.8$ & $22.4 \pm 1.4$ & $25 \pm 2.4$ & $76 \pm 59$ & $126 \pm 118$ \\
\hline Romania & $177.3 \pm 4.6$ & $69.7 \pm 6.2$ & $22.1 \pm 1.6$ & $26 \pm 3.2 *$ & $65 \pm 47$ & $201 \pm 207^{*}$ \\
\hline Hungary & $176.8 \pm 5.7$ & $67.6 \pm 6.3$ & $21.5 \pm 1.3$ & $23 \pm 3$ & $34 \pm 38$ & $85 \pm 126$ \\
\hline Austria & $174.5 \pm 5.8$ & $66 \pm 6.4$ & $21.6 \pm 1.4$ & $21 \pm 3.9 * * *$ & $52 \pm 52$ & $139 \pm 199$ \\
\hline Angola & $174 \pm 6.9$ & $69 \pm 9.7$ & $22.7 \pm 2.3$ & $24 \pm 3.3$ & $15 \pm 28 * * *$ & $10 \pm 28 * *$ \\
\hline China & $178.8 \pm 4.7 * *$ & $68.1 \pm 4.7$ & $21.3 \pm 1$ & $22 \pm 3.5^{*}$ & $47 \pm 40$ & \\
\hline Sweden & $177 \pm 5.8$ & $71.7 \pm 6.1$ & $22.8 \pm 1$ & $25 \pm 3$ & $55 \pm 49$ & $120 \pm 116$ \\
\hline Tunisia & $172 \pm 6$ & $65.3 \pm 6.5$ & $22 \pm 1.6$ & $23 \pm 4$ & $69 \pm 69$ & $245 \pm 287 * * *$ \\
\hline Brazil & $176.6 \pm 7$ & $70 \pm 6.8$ & $22.3 \pm 1$ & $25 \pm 2.8$ & $46 \pm 38$ & $88 \pm 72$ \\
\hline Japan & $167.6 \pm 5.8 * * * *$ & $63.1 \pm 4.8^{* * *}$ & $22.4 \pm 1.5$ & $25 \pm 3$ & $24 \pm 28$ & $63 \pm 75$ \\
\hline Ukraine & $178.8 \pm 8^{*}$ & $68.8 \pm 7.1$ & $21.4 \pm 0.8$ & $26 \pm 4.1$ & $28 \pm 20$ & $75 \pm 71$ \\
\hline Ivory Coast & $175.3 \pm 5.4$ & $74.7 \pm 9.9 * * *$ & $24.2 \pm 2.3 * * * *$ & $27 \pm 4.1 * * * *$ & & \\
\hline Argentina & $172.1 \pm 5.7$ & $67.6 \pm 6.8$ & $22.8 \pm 1.3$ & $23 \pm 3.5$ & $47 \pm 28$ & $98 \pm 65$ \\
\hline Congo & $168 \pm 5.8 * * * *$ & $69.7 \pm 8.5$ & $24.6 \pm 2.1 * * * *$ & $26 \pm 4.6$ & $18 \pm 9 *$ & $47 \pm 26^{* * *}$ \\
\hline Thailand & $166.6 \pm 4.8 * * * *$ & $61.1 \pm 6.5^{* * * *}$ & $21.9 \pm 1.9$ & $20 \pm 2.6^{* * * *}$ & $1 \pm 1 * * * *$ & $10 \pm 8$ \\
\hline Kazakhstan & $179.8 \pm 6.8 * * *$ & $72.8 \pm 10.7 *$ & $22.4 \pm 2.3$ & $22 \pm 4.4$ & & \\
\hline Chile & $165.5 \pm 5.2 * * * *$ & $64.5 \pm 8$ & $23.5 \pm 2.5^{* *}$ & $22 \pm 2.9$ & & \\
\hline Australia & $174.4 \pm 6$ & $68.7 \pm 8.8$ & $22.5 \pm 2.2$ & $22.8 \pm 5$ & $10 \pm 20 * * *$ & $16 \pm 26^{* *}$ \\
\hline
\end{tabular}

Note. ${ }^{*}-\mathrm{p}<0.05 ; * *-\mathrm{p}<0.02 ; * * *-\mathrm{p}<0.01 ; * * * *-\mathrm{p}<0,001$ compared with the average value.

$(\mathrm{p}<0.001)$ international matches compared to the players of $1-4$ teams $(\mathrm{ES}=0.600$ [moderate] ) and of 5-12 teams $(\mathrm{ES}=0.401$ [small]). European players had played significantly more international matches compared to the ones of other continents $(p<0.01-$ 0.001; ES $=$ small) except Australian continent $(\mathrm{ES}=1.304$ [large] $)$ and insignificantly compared to American handball players. Australian handball players had played less international matches than the players from America ( $<<0.001$; ES $=1.360$ [large]) and Asia $(\mathrm{p}<0.05 ; \mathrm{ES}=0.779$ [moderate]).
Sports experience (goals scored). The players of 1-4 teams had scored more goals than the players of the lowest 13-24 teams ( $<<0.01 ; \mathrm{ES}=0.462$ [small]) (Tables 1,2). European handball players had scored more goals compared to players of the Asian continent ( $\mathrm{p}<0.05 ; \mathrm{ES}=0.373$ [small]). Australian handball players had scored fewer goals than the player of the tournament on average $(\mathrm{p}<0.05$; $\mathrm{ES}=$ 1.097 [moderate]), the champions - Russian players $(\mathrm{p}<0.02 ; \mathrm{ES}=1.317$ [large] $)$, European players $(\mathrm{p}<0.02 ; \mathrm{ES}=1.329$ [large] $)$, and the players of America $(\mathrm{p}<0.001$; ES $=3.748$ [very large]). 


\section{DISCUSSION}

The results of our research are in line with other researchers who have claimed that the successful outcome of the game is mainly due to handball players' physique (height, body mass) (Bayios et al., 2006; Hasan et al., 2007; Massuca, 2011; Michalsik et al., 2011) body fat and muscle ratio (Vila et al., 2011). Handball players with greater experience have a greater chance of winning a match-play (Schneider et al. 2007; Skarbalius, 2009). Such trend was established in the WWHC'2009. The players of the European continent and players representing the teams winning 1-4 places were more experienced, taller, older and heavier than the players of the WWHC'2009 on average. The same tendency was established in the last European Women's Handball Championship'2010 (Joergensen, 2010). It should be noted that the players of the European Women's Handball Championship'2010 were taller and heavier than WWHC'2009 participants. Handball players were getting taller over time (Taborsky, 2007) such as athletes in many sports have been getting taller and more massive. It could be affirmed that the handball female players were getting bigger at a faster rate than that predicted by the secular trend alone and it is in the line to athletes' development in general (Norton, Olds, 2001).

The question is how players' height and body mass, and BMI influenced sports results. The height of players was a significant indicator to win a match-play $(\mathrm{r}=0.551 ; \mathrm{p}<0.001 ; \mathrm{Y}=0.7627 \mathrm{x}-$ 121.93; $\mathrm{r}^{2}=0.3043$ ) (Figure 1). As the competition system of the WWHC'2009 was divided into stages (preliminary, main round, and final) with different mastership level of participating teams, it did not allow teams to take the highest places $(\mathrm{r}=-0.278 ; \mathrm{p}<0.01)$ in the ranking scale adequate to their mastership level. It can be concluded that the final result of match-play may be influenced by other factors (Hughes, Frank, 2006).

Contrary to the height the body mass indices had a negative impact on winning a match-play $\left(\mathrm{r}=0.317 ; \mathrm{p}<0.01 ; \mathrm{Y}=0.05353 \mathrm{x}-25.598 ; \mathrm{r}^{2}=0.1008\right)$, winning the tournament score and even to predict the championship places for the teams $(r=-0.067)$ (Figure 2). In consequence, greater body mass of players was the limiting factor to win a matchplay. This is controversial compared to elite men's handball (Skarbalius, 2009). Negative influence of body mass on sports results in WWHC'2009 could be explained by the phenomenon of the ratio of muscle and fat mass in females (Hatzimanouil et al., 2005). BMI had a negative impact on winning a match-play $(\mathrm{r}=-0.33005 ; \mathrm{Y}=-2.0762 \mathrm{x}+57.273$; $\left.\mathrm{r}^{2}=0.1089\right)$ and winning the tournament score $(r=-0.230 ; p<0.01)$ (Figure 3).

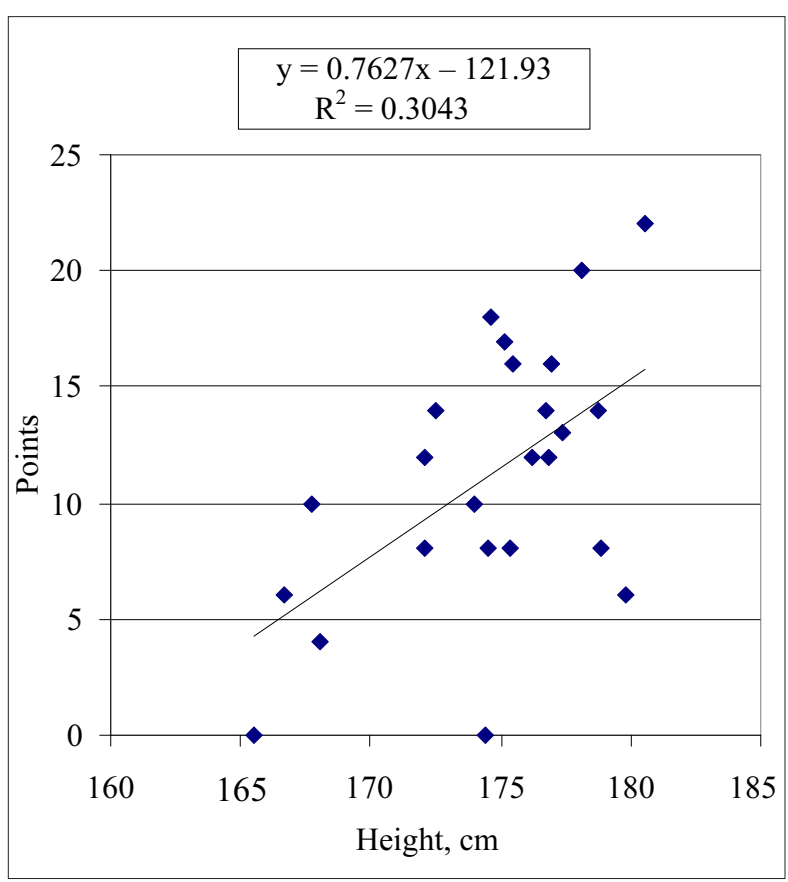

Figure 1. Relationship between players' height and winning points in WWHC'2009

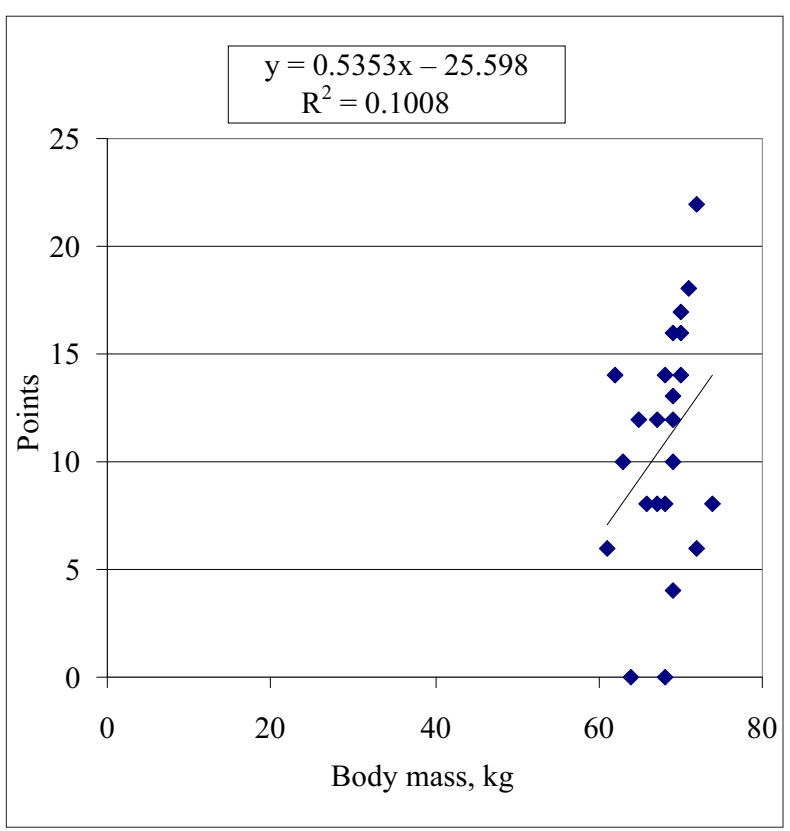

Figure 2. Relationship between players' body mass and winning points in WWHC'2009

High-performing athletes are characterized by sporting experience which is highly related to the age of athletes as well (Skarbalius, 2009). F. Taborsky (2011) asserts that the handball players 


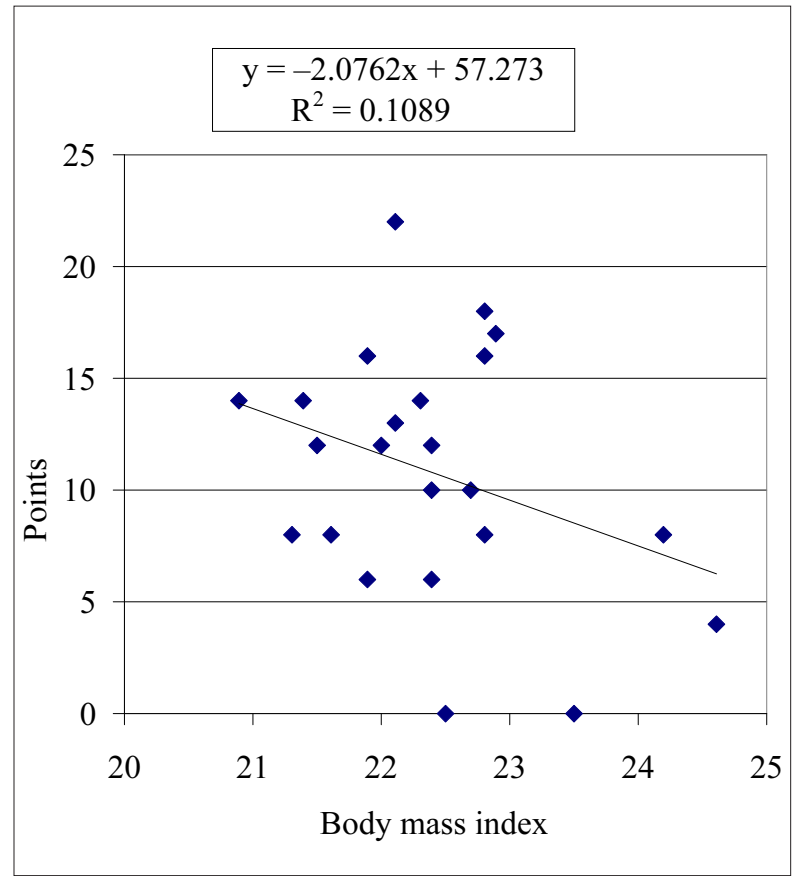

Figure 3. Relationship between players' BMI and winning points in WWHC'2009

who participated more in high-level competitions are superior and more mentally fit. Teams, the players of which had more sports experience (international matches played), had more chances of winning a match-play $(\mathrm{r}=0.719 ; \mathrm{p}<0.001$; $\left.\mathrm{Y}=0.1571 \mathrm{x}+4.9104 ; \mathrm{r}^{2}=0.5183\right)$ and possibilities to take higher places $(r=0.356 ; p<0.01)$ (Figure 4). The players of the teams of higher positions (1-12) in the ranking scale had played more than 40 matches. Another indicator of sports experience (goals scored) had a significant impact on winning a match-play in the WWHC'2009 ( $\mathrm{r}=0.655$; $\left.\mathrm{p}<0.001 ; \mathrm{Y}=0.052 \mathrm{x}+6.5346 ; \mathrm{r}^{2}=0.4296\right)$ (Figure 5). One more significant indicator was the age of players for winning a match-play $(\mathrm{r}=0.504$; $\left.\mathrm{p}<0.001 ; \mathrm{Y}=1.5641 \mathrm{x}+26.372 ; \mathrm{r}^{2}=0.2547\right)$ (Figure 6). However, a weak relationship was found betweentheageandthefinal placesintherankingscale $(\mathrm{r}=-0.154, \mathrm{p}<0.01)$. Such contraversial findings might be explained by not valid enough competition system for the mastership of participating teams (while the teams were divided into groups based on subjective criteria) in WWHC'2009.

On the other hand, such controversial findings might be explained on the variation of interaction during athletes' mastership development. Researchers suggest (Mujika, 2007; Pyke, 2009) that athletes' fitness might be highly correlated with sports results in the group of people varying greatly in fitness, but the correlation may be much lower if similar studies are conducted on a group consisting entirely of elite athletes. The results of WWHC'2009 might be considered to be in line to G. Laffaye and T. Debanne (2011) who stated that within elite handball population height or body mass did not guarantee throwing the ball quickly.

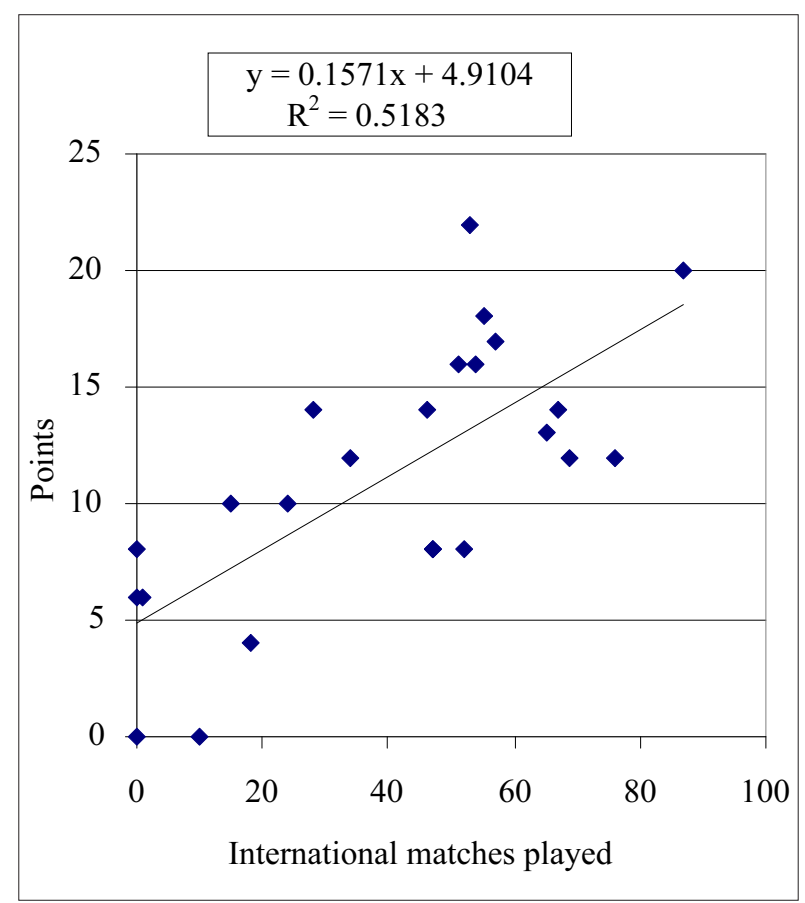

Figure 4. Relationship between players' sports experience (international matches played) and winning points in WWHC'2009

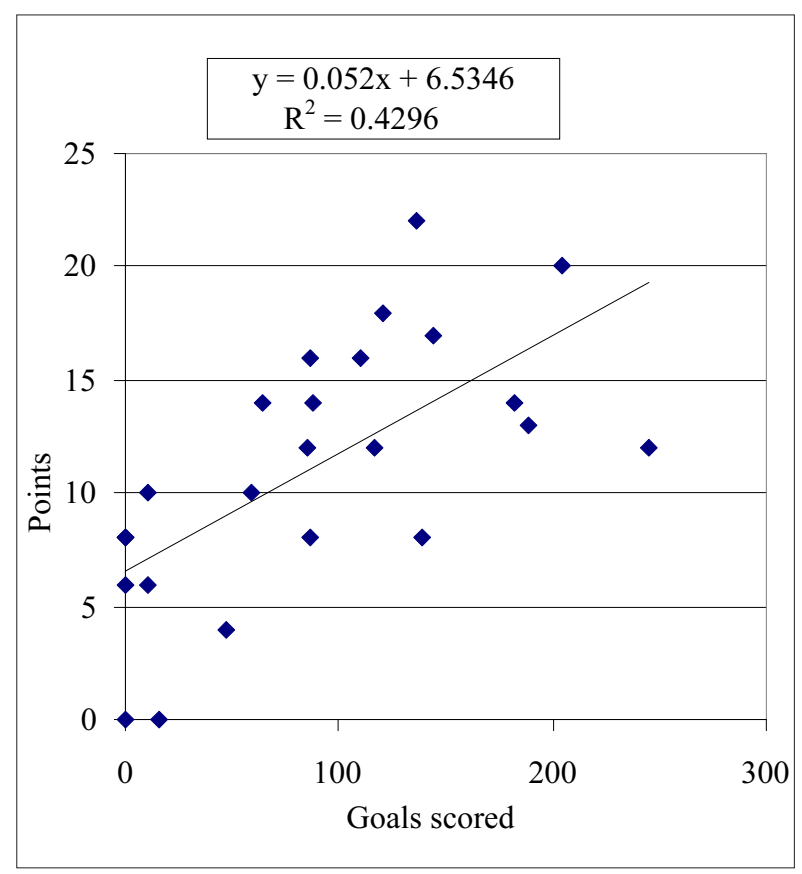

Figure 5. Relationship between players' sports experience (goals scored) and winning points in WWHC'2009 


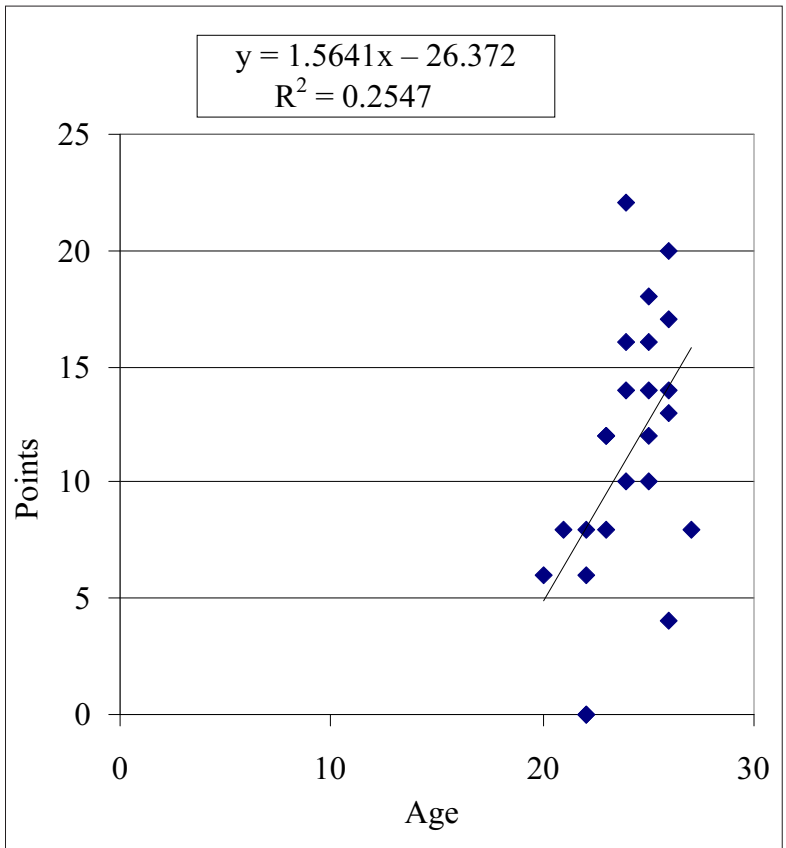

Figure 6 . Relationship between players' age and winning points in WWHC'2009

\section{CONCLUSIONS AND PERSPECTIVES}

Older handball female players, which meant greater sports experience (international matches played and the goals scored), had more possibilities to win in the WWHC'2009.

Sports experience had higher influence than body size (height and body mass) in winning the matches played.

The indices of body mass and BMI had negative influence on winning of match-play.

Future research is needed to reveal the key discriminated indicators for sport performance between winners and losers.

\section{REFERENCES}

Bayios, I. A., Bergeles, N. K., Apostolidis, N. G., Noutsos, K. S., Koskolou, M. D. (2006). Anthropometric, body composition and somatotype differences of Greek elite female basketball, volleyball and handball players. Journal of Sports Medicine and Physical Fitness, 46 (2), 271-280.

Bezerra, E. S., Simão, R. (2006). Anthropometric characteristics of handball adult athletes. Fitness Performance Journal, 5 (5), 14-24.

Carter, J. E. L. (1984). Somatotypes of Olympic athletes. In J. E. L. Carter (Ed.). Physical Structure of Olympic Athletes. Part II: Kinanthropometry of Olympic Athletes. Karger, Basel (pp. 801-809).

Hasan, A. A. A., Rahaman, J. A., Cable, N. T., Reilly, T. (2007). Anthropometric profile of elite male handball players in Asia. Biology of Sport, 24 (1), 3-12.

Hatzimanouil, D., Oxizoglou, N., Hatzimanouil, A., Pantos, P., Rizos, S. (2005). Anthropometric characteristics of elite athletes in team sports. Inguiries in Sport \& Physical Education, 3 (2), 131-140.

Hopkins, W. G. (2002). A scale of magnitudes for effect statistics [20 03 2010]. Internet link: http://sportsci.org/ resource/stats/effectmag.html.

Hopkins, W. G. (2006). Spreadsheets for analysis of controlled trials, with adjustment for a subject characteristic. Sportscience $\left[\begin{array}{lll}25 & 01 & 2010\end{array}\right]$ Internet link: http://www.sportsci.org/resource/stats/ xPostOnlyCrossover.xls.

Hughes, M., Franks, I. M. (2006). Notational Analysis of Sport. London: Routledge.

Joergensen, U. (2010). Women's European Championship 2010 Qualitative analysis. [2011 10 10].
Internet link: http://home.eurohandball.com/ehf files/ specificHBI/ECh_Analyses/2010/DEN/3/Trend $\% 20$ Analysis.pdf

Jones, N. M. P., James, N., Mellalieu, S. D. (2008). An objective method for depicting team performance in elite professional rugby union. Journal of Sports Sciences, 26 (7), 691-700.

Laffaye, G., Debanne, T. (2011). Prediction of ball velocity during standing throw and gain of velocity obtained by cross-over step. EHF Scientific Conference 2011: Science and Analytical Expertise in Handball (pp. 267-272). Vienna: EHF.

Massuca, L. M. (2011). The relative age effect in body size and success of word-class handball players. $E H F$ Scientific Conference 2011: Science and Analytical Expertise in Handball (pp. 156-161). Vienna: EHF

Michalsik, B. L., Madsen, K., Aagaard, P. (2011). Technical match characteristics and influence of body anthropometry in female elite team handball players. EHF Scientific Conference 2011: Science and Analytical Expertise in Handball (pp. 180-185). Vienna: EHF

Mujika, I. (2007). Thoughts and Considerations for Team-Sport Peaking. Olympic Coach, 18 (4), 3-5.

Norton, K., Olds, T. (2001). Morphological evolution of athletes over the 20th century. Sports Medicine, 31 (11), $763-783$.

Pyke, F. S. (2009). Better Coching. Advanced Coach's Manual. Australian Sports Commission.

Schneider, A. T., Schneider, I. L. M., da Cunha Junior, A. T., Kalinine, I. (2007). Psychic health and social health of the athletes of the feminine Olympic selection of Brazil handball. Fitness \& Performance Journal, 6 (5), 325-330. 
Skarbalius, A. (2009). Olimpinių žaidynių vyrų rankininkų ūgio, kūno masès, amžiaus, varžybinès patirties tendencijos ir ryšio su sportiniais rezultatais ypatumai. Ugdymas. Kūno kultūra. Sportas, 1 (72), 123-130.

Taborsky, F. (2011). Competitive Loading in Top Team Handball and the Consequences for Training [2011 12 15]. Internet link: http://home.eurohandball. com/ehf files/Publikation/WP Competitive\%20 Loading\%20in\%20Top\%20Team $\% \overline{2}$ 0Handball.pdf
Taborsky, F. (2007). The Body Height and Top Team handball players [2012 01 11]. Internet link: http:// home.eurohandball.com/ehf_files/Publikation/WP Taborsky-Body\%20height.pdf

Vila, H., Manchado, C., Abraldes, A. et al. (2011). Anthrophometric profile in female elite handball players by playing positions. EHF Scientific Conference 2011: Science and Analytical Expertise in handball (pp. 219221). Vienna: EHF.

\title{
PASAULIO MOTERŲ RANKINIO ČEMPIONATO'2009 ŽAIDE்JŲ ANTROPOMETRINIŲ RODIKLIŲ, VARŽYBINĖS PATIRTIES RYŠYS SU SPORTINIAIS REZULTATAIS
}

\author{
Audinga Kniubaitė, Antanas Skarbalius \\ Lietuvos kūno kultūros akademija, Kaunas, Lietuva
}

\section{SANTRAUKA}

Tyrimo pagrindimas ir hipotezė. Sportininkų parengtumas lemia sportinius rezultatus. Rankinio varžybinė veikla kompleksiška, dèl to žaidimo ypatumai gali būti analizuojami ịvairiais būdais. Elito rankininkių kūno sudẻjimo ir sportinės patirties ryšys su sportiniais rezultatais leistų atskleisti ypatumus, būdingus ne tik konkrečioms aukščiausio rango varžyboms, bet ir sudarytų prielaidas spręsti apie elito rankinio tendencijas. Keliama hipotezė, kad komandos, kurių žaidèjos yra aukštesnès, didesnès kūno masès ir sportinès patirties, turi daugiau galimybių laimèti rungtynes.

Tikslas - nustatyti ir įvertinti 2009 metų pasaulio moterų rankinio čempionato komandų ūgio, kūno masès, kūno masės indekso (KMI), amžiaus, varžybinės patirties ryši su sportiniais rezultatais.

Metodai. Iš viešai prieinamo Pasaulio rankinio federacijos puslapio duomenų bazès (http//www.ihf.info) atlikta paskutinio 2009 m. XIX moterų rankinio pasaulio čempionato (24 komandų) 390 žaidejjų antropometrinių rodiklių (ūgio ir kūno masės), amžiaus, varžybinės patirties (šalies rinktinei atstovautų rungtynių ir įmestų įvarčių skaičiaus) lyginamoji analizė (skirtumų patikimumas nustatytas Stjudento $t$ kriterijumi taikant $95 \%$ reikšmingumo lygmeni $\mathrm{p}<0,05$ ). Minètų rodikliu ryšiui su sportiniais rezultatais (pelnytais taškais ir užimtomis vietomis) nustatyti buvo taikyti Pirsono ir Spirmeno koreliacijos koeficientai.

Rezultatai. Čempionès Rusijos žaidèjos, pirmujų keturių vietų rankininkès ir europietès buvo aukščiausios ir didžiausios sportinès patirties.

Aptarimas ir išvados. Čempionato rungtynių sėkmę lèmė varžybinės patirties rodikliai. Didesnès patirties žaidèjos (pagal žaistų tarptautinių rungtynių rodikli) turèjo daugiau galimybių laimèti rungtynes $(r=0,719 ; p<0,001$; $\left.\mathrm{Y}=0,1571 \mathrm{x}+4,9104 ; \mathrm{r}^{2}=0,5183\right)$ ir užimti aukštesnes vietas $(\mathrm{r}=-0,356 ; \mathrm{p}<0,01)$, tačiau neigiamą poveiki turèjo kūno masė $\left(r=0,317 ; \mathrm{Y}=0,5353 \mathrm{x}-25,598 ; \mathrm{r}^{2}=0,1008\right)$ ir KMI $\left(\mathrm{r}=-0,3300 ; \mathrm{Y}=-2,0762 \mathrm{x}+57,273 ; \mathrm{r}^{2}=0,1089\right)$. Paskutinio 2010 metų Europos moterų rankinio čempionato rankininkès (www.eurohandball.com) buvo aukštesnès ir didesnès kūno masès negu PC'2009 dalyvès.

Raktažodžiai: moterų rankinis, kūno masè, ūgis.

Gauta 2012 m. sausio 19 d.

Received on January 19, 2012

Corresponding author Antanas Skarbalius Lithuanian Academy of Physical Education Sporto str. 6, LT-3000 Kaunas

Lithuania

Tel +370-37 209144

E-mail a.skarbalius@1kka.1t 